\title{
EFISIENSI PENGGUNAAN Trichoderma sp UNTUK MENGENDALIKAN PENYAKIT LAYU FUSARIUM (Fusarium oxys porium) DAN PERTUMBUHAN BIBIT TANAMAN PISANG
}

\author{
USE EFFICIENCY OF TRICHODERMAS FOR CONTROL FUSARIUM WOOD \\ DISEASES (Fusarium oxysporium) AND GROWTH ON BANANA PLANT
}

\author{
Bukhari dan Nuryulsen Safridar*) \\ Program Studi Agroteknologi Universitas Jabal Ghafur \\ Bukhari mp@gmail.com, nuryulsens afrida@gmail.com
}

\begin{abstract}
This research was conducted in Pante Cermin, Padang Tiji Subdistrict, Pidie District. in March to August 2015, with the aim to know the use efficienci of Trichoderma sp on the growth of several types of Banana seedlings (Musa Paracica L.) This research using Randomized Block Design (RAK) factorial pattern with the factors studied is the type of banana and trichoderma dose . Both factors consist of 4 levels: Banana Barangan $\left(\mathrm{J}_{1}\right)$, Ambon banana $\left(\mathrm{J}_{2}\right)$, Banana King $\left(\mathrm{J}_{3}\right)$ and Geupok banana $\left(\mathrm{J}_{4}\right)$. While the dose of Tricoderma sp is: $\mathrm{T}_{\mathrm{O}}=0 \mathrm{~g} /$ seeds $\mathrm{T}_{1}=15 \mathrm{~g} / \mathrm{seeds} \mathrm{T}_{2}=30 \mathrm{~g} /$ seedlings and $\mathrm{T}_{3}=45 \mathrm{~g} /$ seedlings. So there are 16 treatment combinations and repeated 3 times, which resulted in 48 experimental units.

To determine the influence of each treatment and its interaction on the growth of banana seedlings, the analysis of variance (Test F) and continued with the test of Beda Nyata Jujur (BNJ) at 5\% level.

The results showed that the growth of good banana seedlings among 4 species studied was shown by Barangan bananas, but not unlike bananas. However, trichoderma administration until the age of 4 months has not shown the growth and intensity of different attacks. So it should be extended the study period to 6 months. After 6 months of research there has been a difference in growth and intensity of attack, where the intensity of the greatest attack is shown by T0 (without trichoderma). Medium intensity of smallest attack is shown by T3 (Dose trichoderma sp 45 gr / banana seedlings). The type of banana does not affect the growth and intensity of fusarium wilt attack. and the interaction of these two factors had no significant effect on the growth of banana seedlings and the intensity of Fusarium wilt disease.
\end{abstract}

Keywords: Trichoderma sp, banana, wilt Fusarium oxyspor um

\section{ABSTRAK}

Penelitian ini dilakukan di Pante Cermin Kecamatan Padang Tiji Kabupaten Pidie. pada bulan Maret sampai dengan bulan Agustus 2015, dengan tujuan untuk mengetahui efisiensi penggunaan Trichoderma sp terhadap pertumbuhan beberapa 
jenis bibit Pisang (Musa Paracica L.) Penelitian ini mengunakan Rancangan Acak Kelompok (RAK) pola faktorial dengan faktor yang diteliti adalah Jenis pisang dan dosis trichoderma. Kedua faktor terdiri dari 4 taraf yaitu: Pisang Barangan $\left(\mathrm{J}_{1}\right)$,pisang Ambon $\left(\mathrm{J}_{2}\right)$, pisang Raja $\left(\mathrm{G}_{3}\right)$ dan pisang Geupok $\left(\mathrm{J}_{4}\right)$. Sedangkan dosis Tricoderma sp yaitu $: \mathrm{T}_{\mathrm{O}}=0 \mathrm{~g} / \mathrm{bibit} \mathrm{T}_{1}=15 \mathrm{~g} /$ bibit $\mathrm{T}_{2}=30 \mathrm{~g} / \mathrm{bibit}$ dan $\mathrm{T}_{3}=45 \mathrm{~g} /$ bibit. Sehingga terdapat 16 kombinasi perlakuan dan diulang 3 kali, yang menghasilkan 48 satuan percobaan.

Untuk mengetahui pengaruh masing-masing perlakuan serta interaksinya terhadap pertumbuhan bibit pisang, dilakukan analisis ragam (Uji F) dan dilanjutkan dengan uji Beda Nyata Jujur (BNJ) pada taraf 5\%.

Hasil penelitian menunjukkan bahwa secara fisul pertumbuhan bibit pisang yang baik diantara 4 jenis yang diteliti ditunjukkkan oleh pisang Barangan namun secara statistika tidak berbeda dengan pisang 3 jenis pisang lainnya. Namun pemberian trichoderma sampai umur 4 bulan belum memeperlihatkan pertumbuhan dan intensitas serangan yang berbeda nyata, sehingga harus diperpanjang masa penelitian menjadi 6 Bulan. Setelah 6 bulan penelitian ternyata telah ada perbedaan pertumbuhan dan intensitas serangan, dimana intensitas serangan yang paling besar diperlihatkan oleh $\mathrm{T}_{0}$ (tanpa pemberian trichoderma). Sedang intensitas serangan terkecil diperlihatkan oleh $\mathrm{T}_{3}$ (Dosis trichoderma sp $45 \mathrm{gr} / \mathrm{bibit}$ pisang). Jenis pisang tidak berpengaruh terhadap pertumbuhan dan Intensitas serangan layu fusarium. serta interaksi kedua faktor tersebut berpengaruh tidak nyata terhadap pertumbuhan bibit pisang dan intensitas serangan penyakit layu Fusarium.

\section{Kata kunci: Trichoderma sp, pisang, layu Fusarium oxysporium}

\section{PENDAHULUAN}

\section{Latar Belakang}

Padang Tijie merupakan salah satu daerah centra produksi pisang di Aceh, namun akhir-akhir ini hampir semua varietas pisang mengalami serangan penyakit layu Fusarium yang rata-rata mengakibatkan kematian dan penurunan produksi tanaman pisang, penyakit layu Fusarium oxysporum yang berkembang begitu cepat dan mampu menginfeksi rumpun-rumpun pisang sehingga menyulitkan pengembangan tanaman ini dan menimbulkan kerugian yang cukup besar bagi petani pisang di daerah

$$
\text { Produktifitas pisang }
$$

Padang Tiji tersebut yang sebelumnya merupakan daerah centra produksi pisang di Aceh. Menurut Sitepu $d k k$., (2015) penyakit layu Fusarium ini telah merusak tanaman pisang di propinsi Sumatra Utara terutama di Sibiru-biru Kabupaten Simalungun. Penyakit ini telah mewabah di Indonesia sehingga memerlukan penanganan segera agar petani pisang tidak terus-terusan mengalami kegagalan usaha yang menyeret mereka kepada kemiskinan.

dipengaruhi oleh banyak faktor, salah 
satunya adalah kualitas bibit. Terbatasnya bibit berkualitas diantara tahan terhadap penyakit layu menyebabkan rendahnya produktifitas tanaman pisang. Akhir-akhir ini banyak tanaman yang terserang bahkan ada kebun-kebun pisang yang gagal panen akibatnya banyak petani pisang yang kehilangan penghasilan sehingga menjadi miskin. Untuk membangkitkan kembali semangat petani dalam mengembangkan tanaman pisang, dibutuhkan bibit Salah satu terobosan tersebut adalah pemanfaatan Trichoderma sp, jamur tersebut tersebut berfunghsi sebagai bioantagonis dan biofertilizer penyubur tanaman guna memperoleh kualitas bibit pisang yang baik. Penggunaan bahan biokomplek Trichoderma sp dapat menyebabkan tanaman lebih tahan terhadap penyakit, produksi tinggi dan agroekosistem aman (Dwiastuti, dkk., 2015). Dosis anjuran trichoderma ini ini adalah 30 - $90 \mathrm{~g}$ dalam satu lubang tanam ( Azwar, 2008). Penggunaan Trichoderma sp bermanfaat bagi bibit untuk mencegah serangan penyakit,

\section{Rumusan Masalah}

1. Apakah jenis pisang berepengaruh terhadap pertumbuhan dan intensitas serangan penyakit layu fusarium.

2. Apakah penggunaan Trichoderma sp dapat menghasilkan bibit tanaman pisang yang lebih

\section{Tujuan Penelitian}

Penelitian ini bertujuan untuk:

1. Mengetahui pengaruh jenis pisang terhadap pertumbuhan bibit pisang dan Intensitas serangan penyakit layu fusarium. pisang yang berkualitas termasuk bebas dari serangan penyakit layu fusarium, yang akan ditanami pada pengembengani kebun baru maupun untuk kebutuhan sulaman. Demi memenuhi kebutuhan bibit pisang yang semakin besar menuntut terobosan baru dengan cara menggunakan teknologi tepat guna sehingga dapat memenuhi kebutuhan bibit pisang dari jenis yang mempunyai kualitas baik (Azwar, 2008).

rebah kecambah, meningkatkan ketegaran bibit, mencegah serangan penyakit layu dan meningkatkan kesuburan tanah. Pemberian Trichoderma sp tersebut diharapkan dapat melancarkan aktifitas metabolisme tanaman, sehingga pertumbuhan dan hasil tanaman meningkat (Siregar, 2000). Namun apakah trichoderma sp efektif digunakan pada tanaman pisang, lalu apakah semua jenis pisang dapat menyesuaikan diri dengan trichoderma sp untuk mencegah serangan penyakit layu Fusariun oxysporium menghendaki suatu penelitian.

berkualitas yakni bebas dari serangan penyakit layu fusarium.

3. Apakah intraksi kedua faktor tersebut berpengaruh terhadap pertumbuhan dan intensitas bibit pisang.

2. Mengetahui pengaruh penggunaan Trichoderma sp terhadap intensitas seranganb penyakit lkayu fusarium dan pertumbuhan bibit pisang (Musa paradicica. L.). 


\section{Mengetahui pengaruh interaksi terhadap intensitas}

\section{Hipotesis}

1. Jenis pisang berpengaruh terhadap pertumbuhan bibit dan intensitas serangan penyakit layu fusarium.

2. Pemanfaatan jamur anta gonis trichoderma sp berpengaruh terhadap pertumbuhan bibit pisang dan intensitas serangan serangan dan pertumbuhan bibit pisang.

\section{METODE PENELITIAN}

\section{Tempat dan Waktu}

Penelitian ini dilakukan di Desa Pante Cermin Kecamatan Padang Tiji Kabupaten Pidie. Penelitian ini

\section{Alat dan Bahan Penelitian.}

\section{Alat-Alat}

Alat yang digunakan untuk menunjang pelaksanaan penelitian ini antara lain:

cangkul, handsprayer (volume 14 liter), parang, bambu, tali rafia, ayakan

\section{Bahan-Bahan}

Bahan yang digunakan dalam penelitian ini adalah: Bonggol 4 jenis pisang, tanah top soil, trichoderma sp,

\section{Rancangan Penelitian.}

Penelitian ini mengunakan Rancangan Acak Kelompok (RAK) pola faktorial penyakit layu fusarium.

3. Interaksi antara jenis pisang dan pemberian trichoderma $\mathrm{sp}$ berpengaruh terhadap pertumbuhan bibit pisang dan intensitas serangan penyakit layu fusarium.. dilaksanakan pada bulan Maret sampai dengan bulan Agustus 2015

tanah, plastik putih, daun kelapa, corong, jangka sorong, timbangan analitik dan peralatan lain yang mendukung penelitian

pupuk kandang, polybag dan pestisida organik ektrak daun mimba.

dengan faktor yang di teliti terdiri dari

1. Jenis pisang $(\mathbf{J})$ terdiri dari 4 taraf 
Yaitu $\left(\mathrm{J}_{1}\right)$ pisang barangan, $\left(\mathrm{J}_{2}\right)$ pisang Ambon, $\left(\mathrm{J}_{3}\right)$ pisang Raja dan $\left(\mathrm{J}_{4}\right)$ Pisang Geupok.

2. Dosis Trichoderma sp juga

Dengan demikian terdapat 16 kombinasi perlakuan dan diulang 3 kali, sehingga terdapat 48 satuan percobaan. Susunan kombinasi perlakuan dapat di lihat pada tabel 1 . Untuk mengetahui pengaruh masing- terdiri dari 4 taraf yaitu $:\left(\mathrm{T}_{\mathrm{O}}\right)=0$ g/ bibit tanaman, $\left(\mathrm{T}_{1}\right)=1,5 \mathrm{~g} / \mathrm{bibit}$ tanaman, $\quad\left(\mathrm{T}_{2}\right)=2 \mathrm{~g} /$ bibit tanaman dan $\left(\mathrm{T}_{3}\right)=2,5 \mathrm{~g} / \mathrm{bibit}$ tanaman.

Tabel 1. susunan kombinasi perlakuan antara Jenis pisang dan Trichoderma.

\begin{tabular}{|c|c|c|c|}
\hline \multirow{2}{*}{ No } & \multirow{2}{*}{$\begin{array}{c}\text { Kombinasi } \\
\text { Perlakuan }\end{array}$} & Jenis & Trichoderma $s p$ \\
\cline { 3 - 4 } & & pisang & gr/bibit tanaman \\
\hline 1. & $\mathrm{~J}_{1} \mathrm{~T}_{0}$ & Barangan & 0 \\
\hline 2. & $\mathrm{~J}_{1} \mathrm{~T}_{1}$ & Barangan & 15 \\
\hline 3. & $\mathrm{~J}_{1} \mathrm{~T}_{2}$ & Barangan & 30 \\
\hline 4. & $\mathrm{~J}_{1} \mathrm{~T}_{3}$ & Barangan & 0 \\
\hline 5. & $\mathrm{~J}_{2} \mathrm{~T}_{0}$ & Ambon & 15 \\
\hline 6. & $\mathrm{~J}_{2} \mathrm{~T}_{1}$ & Ambon & 30 \\
\hline 7. & $\mathrm{~J}_{2} \mathrm{~T}_{2}$ & Ambon & 45 \\
\hline 8. & $\mathrm{~J}_{2} \mathrm{~T}_{3}$ & Ambon & 0 \\
\hline 9. & $\mathrm{~J}_{3} \mathrm{~T}_{0}$ & Raja & 15 \\
\hline 10. & $\mathrm{~J}_{3} \mathrm{~T}_{1}$ & Raja & 30 \\
\hline 11. & $\mathrm{~J}_{3} \mathrm{~T}_{2}$ & Raja & 45 \\
\hline 12. & $\mathrm{~J}_{3} \mathrm{~T}_{3}$ & Raja & 0 \\
\hline 13. & $\mathrm{~J}_{4} \mathrm{~T}_{0}$ & Geupok & 30 \\
\hline 14. & $\mathrm{~J}_{4} \mathrm{Z}_{1}$ & Geupok & 45 \\
\hline 15. & $\mathrm{~J}_{4} \mathrm{~T}_{2}$ & Geupok & \\
\hline 16. & $\mathrm{~J}_{4} \mathrm{~T}_{3}$ & Geupok & \\
\hline
\end{tabular}

Pelaksanaan Penelitian

\section{Persiapan Benih}

Bonggol pisang yang digunakan dipesan dari petani setempat, dari batang yang masih sehat, tumbuh masing faktor perlakuan serta interaksinya terhadap pertumbuhan bibit kakao, dilakukan analisis ragam (Uji F) dan dilanjutkan dengan uji Beda Nyata Jujur (BNJ) pada taraf $5 \%$.

Persiapan Media Tanam

dibagian bawah batang dan mempunyai ukuran normal. 
Media tanam berupa tanah lapisan atas (top soil) diambil pada kedalaman 0-20 cm dari permukaan tanah. Tanah tersebut dikeringanginkan selama satu minggu, selanjutnya dicampur secara homogen dengan pupuk kandang dengan perbandingan 1:1. Kemudian media

\section{Pestisida Organik}

Untuk menghindari serangan hama dan penyakit digunakan biopestisida, dan

\section{Perkecambahan Benih}

Perkecambahan bonggol dilakukan pada media pasir,. benih disusun rapat dengan jarak $10 \mathrm{~cm}$ dan dalam alur 5 $\mathrm{cm}$ serta ditutup dengan goni basah.

\section{Penyapihan}

Sebelum ditanam bibit muda diperlakukan dengan merendam dalam larutan pf ( Pseudomonas fluorencens ) untuk mencegah serangan penyakit busuk bakteri, polybag disusun dibawah naungan pada bedengan dengan jarak antara tepi Selanjutnya media yang telah dimasukkan kedalam polybag ukuran 15 x $30 \mathrm{~cm}$ diberikan Trichoderma sp

\section{Pemeliharaan}

Tindakan pemeliharaan bibit yang diperlukan meliputi penyiraman, pemupukan serta pengendalian hama dan penyakit hingga berumur 6 bulan. Penyiraman dilakukan secukupnya pada sore hari, hingga media tanam lembab dengan menggunakan gembor yang memiliki kapasitas isi 10 liter. Penyulaman tersebut dimasukkan ke dalam polybag sampai $2 \mathrm{~cm}$ dari permukaan polybag, setelah itu disusun sesuai dengan bagan percobaan. Polybag yang dipakai berwarna hitam berukuran 30 x $15 \mathrm{~cm}$ dan tebal $0,25 \mathrm{~mm}$, polybag diberi lubang drainase 10 lubang per polybag dan di isi media.

masing-masing dengan konsentrasi 200 cc ekstrak dalam satu liter air.

Setelah 2 - 3 minggu, sebagian besar benih telah berkecambah dan dapat dicabut lalu dipindahkan kedalam polybag.

sesuai perlakuan serta disiram air secukupnya, kecambah ditanam di bagian, tengah kantong, yakni dilubang yang dibuat dengan jari tugal kayu, bonggol ditanam hati-hati supaya terhindar dari kerusakan akar, setelah ditanam tanah dikanan dan kiri kecambah dipadatkan sedikit dengan jari.

dilakukan satu minggu untuk menjaga pertumbuhan bibit kakao dalam penelitian ini.

Penyiangan tumbuhan pengganggu dilakukan secara manual, tetapi teratur, gulma, baik yang tumbuh di dalam polibag maupun yang tumbuh diluar polibag disiangi. Pemupukan dilakukan ketika bibit kakao berumur 
10 hari setelah pembibitan sesuai perlakuan, untuk menunjang pertumbuhan dan perkembangan bibit pisang. Bibit perlu dilindungi dari serangan hama dan penyakit. Hama yang sering menyerang bibit kakao antara lain, belalang, berbagai macam ulat, siput (bekicot) dan kutu.

\section{Pengamatan}

Parameter yang diamati meliputi:

1. Tinggi bibit.

Tinggi bibit diukur dari leher akar sampai titik tumbuh tertinggi pada umur, 40,80 dan 120 , dinyatakan dalam satuan centi meter.

2. Panjang daun Daun

Panjang daun diukur dari pangkal sampai ke ujung daun diukur pada umur

40, 80 dan 120 hari dengan meteran yang dinyatakan dalam satuan centi

meter $(\mathrm{cm})$. Diameter Batang.

\section{HASIL DAN PEMBAHASAN}

\section{Tinggi Tanaman}

Jenis pisang sangat berpengaruh terhadap pertumbuhan awal bibit pisang, dimana pada saat awal, pertumbuhan bibit yang baik ditunjukkan oleh bibit pisang barangan, namun setelah berumur 120 hari pertumbuhan bibit btidak lagi
Penyakit bisa dikendalikan dengan fungisida atau pestisida yang dianjurkan. Penyakit yang sering menyerang bibit kakao adalah bermacam-macam jamur, seperti fusarium, phytoptora., dan colletotrichum.

3. Jumlah Daun

Jumlah daun dihitung terhadap daun yang telah membuka sempurna pada umur 40, 80 dan 120 hari.

4. Diameter Baatang

Diameter batang diukur pada umur 40, 80 dan 120 dengan menggunakan jangka sorong yang dinyatakan dalam sat meli meter $(\mathrm{mm})$

5. Intensitas serangan Penyak ॥ layu fusarium dilakukan pada umur 40, 80 dan 120 hari menunjukkan perbedaan yang nyata. Pengujian pengaruh jenis pisang dengan menggunakan uji BNJ pada taraf 5\% terhadap rata-rata tinggi bibit pisang umur 40, 80 dan 120 HST ditampilkan pada Tabel 2. 
Tabe1 2. Rata-rata Tinggi Bibit pisang Umur 40, 80 dan 120 Hari Akibat Perbedaan Jenis Pisang.

\begin{tabular}{|l|c|c|c|}
\hline \multirow{2}{*}{ Jenis pisang } & \multicolumn{3}{|c|}{ Tinggi Tanaman (cm) Umur (hari) } \\
\cline { 2 - 4 } & 40 & 80 & 120 \\
\hline Barangan $\left(\mathrm{J}_{1}\right)$ & $19,24 \mathrm{~b}$ & $44,63 \mathrm{~b}$ & 80,13 \\
Ambon $\left(\mathrm{J}_{2}\right)$ & $17,52 \mathrm{a}$ & $42,05 \mathrm{a}$ & 79,74 \\
Raja $\left(\mathrm{J}_{3}\right)$ & $16,28 \mathrm{a}$ & $41,75 \mathrm{a}$ & 78,16 \\
Geupok $\left(\mathrm{J}_{4}\right)$ & $17,21 \mathrm{a}$ & $41,81 \mathrm{a}$ & 80,06 \\
\hline BNJ $(0,05)$ & 1,14 & 2,56 & 2,98 \\
\hline
\end{tabular}

Keterangan : Angka yang diikuti oleh huruf yang sama pada kolom yang sama berbeda tidak nyata pada taraf $\mathrm{a}=5 \%(\mathrm{Uji} \mathrm{BNJ})$.

Dari table 2 terlihat bahwa bibit tertinggi pada umur 40 dan 80 hari ditunjukkan oleh pisang barangan, namun pada umur 120 hari terlihat tinggi bibit tidak lagi berbeda. Hal ini diduga pisang barangan mempunyai karakter tumbuh lebih cepat pada

Hasil Analisis Ragam (Uji F) menunjukkan bahwa dosis trichoderma berpengaruh sangat nyata terhadap tinggi bibit pada umur 40, 80 dan 120 hari. Selanjutnya pengujian

Dari tabel 3, dapat dilihat bahwa pada umur 40, 80 dan 120 hari, rata-rata bibit tertinggi dijumpai pada pemberian trichoderma sp 45 gr/bibit tanaman $\left(\mathrm{T}_{3}\right)$ dengan nilainya $19,20 \mathrm{~cm}$, yang berbeda nyata dengan $\mathrm{T}_{0}$ dan $\mathrm{T}_{1}$. Tetapi secara tidak berbeda nyata dengan perlakuan $T_{2}$, kecuali pada umur 120 hari dengan tinggi bibit 83,06 $\mathrm{cm}$. Sedangkan bibit awal-awal pertumbuhan, namun ketika umur bibit hampir mencapai fase maksimum untuk dipidahkan ke lapangan laju pertumbuhannya menjadi lambat sehingga terlihat tinggi bibit yang hampir sama dari keempat jenis bibit pisang tersebut.

pengaruh Trichoderma sp dengan menggunakan uji BNJ pada taraf 5\% terhadap rata-rata tinggi bibit pisang umur 40, 80 dan 120 hari ditampilkan pada Tabel 3 .

pisang terendah dijumpai pada perlakuan pemberian trichoderma $\mathrm{sp}$ $0 \mathrm{gr} / \mathrm{bibit}\left(\mathrm{T}_{0}\right)$, namun tidak berbeda nyata dengan perlakuan $T_{1}$ dan $T_{2}$ kecuali pada umur 120 hari. Keadaan perbedaan tinggi bibit akibat perbedaan dosis trichoderma sp ini juga dapat dilihat pada gambar 2,3 . Dan 4 
Tabel3. Rata-rata Tinggi Bibit pisang Umur 40, 80 dan 120 Hari Akibat Perbedaan Dosis Trichoderma sp

\begin{tabular}{|l|c|c|c|}
\hline \multirow{2}{*}{ Dosis Trichoderma sp } & \multicolumn{3}{|c|}{ Tinggi Tanaman (cm) Umur (hari) } \\
\cline { 2 - 4 } & 40 & 80 & 120 \\
\hline 0 gr/bibit $\left(\mathrm{T}_{0}\right)$ & $15,24 \mathrm{a}$ & $40,55 \mathrm{a}$ & $76,33 \mathrm{a}$ \\
15 gr/bibit $\left(\mathrm{T}_{1}\right)$ & $16,25 \mathrm{a}$ & $42,25 \mathrm{a}$ & $77,74 \mathrm{a}$ \\
30 /bibit $\left(\mathrm{T}_{2}\right)$ & $18,28 \mathrm{~b}$ & $43,15 \mathrm{~b}$ & $78,16 \mathrm{a}$ \\
45 gr/bibit $\left(\mathrm{T}_{3}\right)$ & $19,20 \mathrm{~b}$ & $44,81 \mathrm{~b}$ & $83,06 \mathrm{~b}$ \\
\hline BNJ $(0,05)$ & 1,14 & 2,56 & 2,98 \\
\hline
\end{tabular}

Keterangan : Angka yang diikuti oleh huruf yang sama pada kolom yang sama berbeda tidak nyata pada taraf $\mathrm{a}=5 \%(\mathrm{Uji} \mathrm{BNJ})$.

Berpengaruhnya pemberian tricodarma sp terhadap tinggi bibit diduga karena jamur tricodarma sp, dapat menyebabkan tanaman lebih tahan terhadap serangan penyakit layu fusarium ( Fusarium oxysporium) karena koloni trichoderma yang lebih banyak $\left(\mathrm{T}_{3}\right)$ mempunyai kemampuan lebih cepat dalam pertumbuhan meselium sehingga adanya perubahan penggunaan metabolit sekundair yang seharusnya digunakan oleh patogen untuk pertumbuhan miseliumnya, sifat antagonis inilah yang membuat patogen penyebab penyakit layu fusarium tidak mampu bersaing sehingga aktifitas metabolismenya terganggu yang menyebabkan

\section{Panjang Daun}

Berbeda dengan tinggi bibit jenis pisang terlihat tidak berpengaruh terhadap panjang daun, dimana jumlah daun pisang baik pada umur 40, 80 serangan paatogen tersebut menjadi terhambat. Hasil penelitian ini relevan dengan penelitian yang dilakukan (Dwiastuti, dkk., 2015) demngan menggunakan Trichoderma spp untuk mengendalikan Layu fusarium spp pada tanaman sawi karena trichoderma lebih cepat merubah hasil metabolit sekundair sehingga tidak dapat dimanfaatkan oleh patogen. Selanjutnya Sudirman dkk., (2011) mendapatkan bahwa trichoderma $s p$ bersifat antagonistik terhadap fusarium yang menghambat perkembangan koloni berupa penghambatan hiperparasitis me sehingga terjadi lisis hifa.

dan 120 hari tidak terlihat perbedaan, panjang daun keempat jenis pisang memeperlihatkan nilai yang hampir sama, dari sini terbukti bahwa karakter 
panjang daun kempat jenis pisang adalah sama sehingga keempat jenis

Hasil Analisis Ragam (Uji F) menunjukkan bahwa pupuk trichoderma sp berpengaruh sangat nyata terhadap panjang daun pada umur 40, 80 dan 120 hari. Selanjutnya pengujian pengaruh pisang memperlihakan rata-rata panjang daun yang tidak berbeda.

Trichoderma sp dengan menggunakan uji BNJ pada taraf $5 \%$ terhadap ratarata panjang daun bibit pisang umur 40, 80 dan 120 hari ditampilkan pada Tabel 4.

Tabel 4. Rata-rata Panjang Daun Bibit pisang Umur 40, 80 dan 120 Hari Akibat Perbedaan Dosis Trichoderma sp

\begin{tabular}{|l|c|c|c|}
\hline \multirow{2}{*}{ Dosis Trichoderma sp } & \multicolumn{3}{|c|}{ Panjang Daun (cm) Umur (hari) } \\
\cline { 2 - 4 } & 40 & 80 & 120 \\
\hline 0 gr/bibit $\left(\mathrm{T}_{0}\right)$ & $9,92 \mathrm{a}$ & $12,26 \mathrm{a}$ & $15,45 \mathrm{a}$ \\
$15 \mathrm{gr} / \mathrm{bibit}\left(\mathrm{T}_{1}\right)$ & $11,30 \mathrm{~b}$ & $13,68 \mathrm{~b}$ & $16,14 \mathrm{a}$ \\
$30 \mathrm{gr} / \mathrm{bibit}\left(\mathrm{T}_{2}\right)$ & $11,95 \mathrm{bc}$ & $14,07 \mathrm{~cd}$ & $17,70 \mathrm{~b}$ \\
$45 \mathrm{gr} / \mathrm{bibit}\left(\mathrm{T}_{3}\right)$ & $12,78 \mathrm{c}$ & $15,57 \mathrm{~d}$ & $19,04 \mathrm{c}$ \\
\hline BNJ $(0,05)$ & 1,29 & 1,38 & 2,07 \\
\hline
\end{tabular}

Keterangan : Angka yang diikuti oleh huruf yang sama pada kolom yang sama berbeda tidak nyata pada taraf $\mathrm{a}=5 \%(\mathrm{Uji} \mathrm{BNJ})$.

Dari tabel 4, terilihat bahwa pada umur 40 dan 80 hari, ada perbedaan panjang daun rata-rata daun bibit pisang terpanjang, daun terpanjang dijumpai pada pemberian trichoderma sp $45 \mathrm{gr} / \mathrm{bibit} \quad\left(\mathrm{T}_{3}\right)$ dengan nilai berturut-turut $12,78 \mathrm{~cm}$, $15,57 \mathrm{~cm}$ dan $19,04 \mathrm{~cm}$ yang berbeda nyata dengan semua perlakuan lainnya, namun tidak berbeda nyata dengan perlakuan $T_{2}$ pada umur 40 dan 80 hari. Sedangkan daun bibit pisang terpendek dijumpai pada perlakuan tanpa trichoderma sp $\left(\mathrm{T}_{0}\right)$ dengan nilai berturut-turut $9,92 \mathrm{~cm}$, $12,26 \mathrm{~cm}$ dan $15,46 \mathrm{~cm}$ yang berbeda nyata dengan semua perlakuan lainnya. Edangkan pada umur 120 panjang daun paada $T_{0}$ dan $T_{1}$ tidak bebeda nyata namun berbeda dengan $\mathrm{T}_{2}$ dan $\mathrm{T}_{3}$, Daun terpanjang terdapat pada perlakuan $T_{3}$.

Pemberian trichoderma sp memperlihatkan pertumbuhan daun yang lebih baik dengan daun bibit yang lebih panjang dibandingkan dengan daun bibit yang tidak diberikan trichoderma sp. Pemberian pada dosis 45 gr/bibit dapat memperlihatkan daun yang lebih panjang dibandingkan dengan pemberian trichoderma sp 15 gr dan 30 gr/bibit, hal ini disebabkan pemberian trichoderma sp lebih banyak diprediksikan terdapat koloni yang lebih banyak sehingga akan menghasilkan miselium yang lebih banyak pula, hal ini akan 
menyebabkan perubahan metabolit sekunder yang lebih banyak yang mengakibatkan kurang ketersedian hasil metabolisme tanman untuk patogen disamping itu trichoderma juga dapat bertindak sebagai biodekompuser yang dapat memperbaiki sifat-sifat tanah sehingga dapat menguntungkan bibit. Hal ini

\section{Jumlah Daun}

Seperti halnya panjang daun hasil analisis ragam (Uji $F)$ juga menunjukkan bahwa jenis tidak berpengaruh terhadap jumlah daun, tetapi dosis trichoderma sp berpengaruh sangat nyata terhadap jumlah daun pada umur 40, 80 dan sesuai pernyataan (Saraswati dan Sumarno, 2008). bahwa Trichoderma termasuk mikro organisme saprofit yang bertindak sebagai biodekomposer bahan organic yang mengandung serat, lignin, dan senyawa organic yang mengandung nitrogen dan karbon dari bahan organik.

Tabel 5. Rata-rata Jumlah Daun Bibit Pisang Umur 20, 40 dan 60 Hari Akibat Perbedaan Dosis Trichoderma sp

\begin{tabular}{|l|c|c|c|}
\hline \multirow{2}{*}{ Dosis Trichoderma sp } & \multicolumn{3}{|c|}{ Jumlah Daun bibit pisang (lembar) Umur (hari) } \\
\cline { 2 - 4 } & 40 & 80 & 120 \\
\hline 0 gr/bibit $\left(\mathrm{T}_{0}\right)$ & $3,12 \mathrm{a}$ & $4,58 \mathrm{a}$ & $5,62 \mathrm{a}$ \\
15 gr/bibit $\left(\mathrm{T}_{1}\right)$ & $3,84 \mathrm{a}$ & $5,25 \mathrm{a}$ & $6,67 \mathrm{a}$ \\
30 gr/bibit $\left(\mathrm{T}_{2}\right)$ & $4,37 \mathrm{~b}$ & $5,84 \mathrm{~b}$ & $7,30 \mathrm{~b}$ \\
45 gr/bibit $\left(\mathrm{T}_{3}\right)$ & $5,00 \mathrm{c}$ & $6,50 \mathrm{c}$ & $8,09 \mathrm{c}$ \\
\hline BNJ (0,05) & 0,94 & 1,02 & 1,14 \\
\hline
\end{tabular}

Keterangan : Angka yang diikuti oleh huruf yang sama pada kolom yang sama berbeda tidak nyata pada taraf $\mathrm{a}=5 \%(\mathrm{Uji} \mathrm{BNJ})$.

Dari tabel 5, dapat dilihat bahwa pada umur 40, 80 dan 120 hari, rata-rata daun bibit pisang terbanyak dijumpai pada pemberian pupuk trichoderma sp 45 gr/bibit $\left(\mathrm{T}_{3}\right)$ dengan nilainya berturut-turut 5,00 lembar, 6,50 lembar dan 8,09 lembar yang berbeda nyata dengan semua
120 hari. Selanjutnya pengujian pengaruh pupuk Trichoderma sp dengan menggunakan uji BNJ pada taraf 5\% terhadap rata-rata jumlah daun bibit pisang umur 40, 80 dan 120 hari ditampilkan pada Tabel 5 . 
perlakuan dengan dosis $45 \mathrm{~g} /$ bibit merupakan dosis yang sangat sesuai sehingga dapat memberikan jumlah

\section{Diameter Batang}

Hasil analisis ragam (Uji $\mathrm{F}$ ) menunjukkan bahwa jenis dan dosis tidak berpengaruh terhadap dimeter bibit batang pada umur 40, 80 dan 120

Dari tabel 6, secara visual dapat dilihat bahwa pada umur 40, 80 dan 120 hari, rata-rata diameter batang bibit pisang terlebar dijumpai pada pemberian pupuk trichoderma sp 45

Sedangkan diameter batang $b$ tersemibit pit dijumpai pada perlakuan pemberian pupuk trichoderma sp 0 gr/bibit $\left(\mathrm{T}_{0}\right)$ dengan nilainya berturut- daun yang lerbih banyak dibandingkan perlakuan lainnya.

Tabel 6. Rata-rata Diameter Batang Bibit pisang Umur 40, 80 dan 120 Hari Akibat Perbedaan Dosis Trichoderma sp

\begin{tabular}{|l|c|c|c|}
\hline \multirow{2}{*}{ Dosis Trichoderma sp } & \multicolumn{3}{|c|}{ Diameter Batang pisang $(\mathrm{cm})$ Umur (hari) } \\
\cline { 2 - 4 } & 40 & 80 & 120 \\
\hline 0 gr/bibit $\left(\mathrm{T}_{0}\right)$ & 8,09 & 10,09 & 11,08 \\
15 gr/bibit $\left(\mathrm{T}_{1}\right)$ & 8,21 & 10,10 & 11,15 \\
30 gr/bibit $\left(\mathrm{T}_{2}\right)$ & 8,25 & 10,17 & 11,20 \\
45 gr/bibit $\left(\mathrm{T}_{3}\right)$ & 8,31 & 11,19 & 11,24 \\
\hline BNJ $(0,05)$ & - & - & - \\
\hline
\end{tabular}

Keterangan : Angka yang diikuti oleh huruf yang sama pada kolom yang sama berbeda tidak nyata pada taraf $\mathrm{a}=5 \%(\mathrm{Uji} \mathrm{BNJ})$.

Hal ini dapat dijelaskan bahwa laju peningkatan diameter yang sangat rendah ini mengakibatkan perbedaan satu perlakuan dengan perlakuan lainnya belum dapat memperlihatkan hari. Walaupun secara statiska tidak terlihat perbedaan namun secara fisual terlihat ada perbedaan diameter batang yang disajikan pada tabel 6 berikut.

gr/bibit $\left(\mathrm{T}_{3}\right)$ dengan nilainya $8,31 \mathrm{~cm}$, $10,19 \mathrm{~cm}$ dan $11,24 \mathrm{~cm}$, namun secara statiska belum berbeda dengan semua perlakuan.

turut $8,09 \mathrm{~cm}, 8,09 \mathrm{~mm}$ dan $11,08 \mathrm{~cm}$, namun secara statika juga tidak berbeda nyata dengan semua perlakuan lainnya. 


\section{Intensitas serangan}

Dari Hasil analisis (Uji F) terlihat bahwa jenis juga tidak berpengaruh terhadap intensitas serangan, tetapi dosis walaupun pada umur 40 hari belum terdapat serangan dan pada umur 80 serangan telah tampak namun belum terdapat perbedaan yang nyata akan tetapi pada umur 120 hari serangan telah berpengaruh sangat nyata (Gambar 5). Selanjutnya pengujian pengaruh Trichoderma $\mathrm{sp}$ dengan menggunakan uji BNJ pada taraf $5 \%$ terhadap rata-rata intesitas serangan layu fusarium bibit umur 80 dan 120 hari ditampilkan pada Tabel 6.

Tabel 6. Rata-rata Intensitas Serangan Layu Fusarium pada Bibit Pisang Umur 80 dan 120 Hari akibat Perbedaan Dosis Trichoderma sp

\begin{tabular}{|l|c|c|}
\hline \multirow{2}{*}{ Dosis Trichoderma sp } & \multicolumn{2}{|c|}{ Diameter Batang pisang $(\mathrm{cm})$ Umur (hari) } \\
\cline { 2 - 3 } & 80 & 120 \\
\hline 0 gr/bibit $\left(\mathrm{T}_{0}\right)$ & 2,92 & $6,13 \mathrm{~b}$ \\
15 gr/bibit $\left(\mathrm{T}_{1}\right)$ & 1,33 & $2,73 \mathrm{a}$ \\
30 gr/bibit $\left(\mathrm{T}_{2}\right)$ & 1,10 & $2,45 \mathrm{a}$ \\
45 gr/bibit $\left(\mathrm{T}_{3}\right)$ & 1,60 & $1,72 \mathrm{a}$ \\
\hline BNJ $(0,05)$ & - & 2,01 \\
\hline
\end{tabular}

Keterangan : Angka yang diikuti oleh huruf yang sama pada kolom yang sama berbeda tidak nyata pada taraf $\mathrm{a}=5 \%(\mathrm{Uji} \mathrm{BNJ})$.

Dari table 6 telihat bahwa intensis serangan layu fusariun rendah pada bibit pisang yang diperlakukan dengan trichoderma sp walaupun pada umur 80 hari belum telihat perbedaan yang nyata namun umur 120 hari telah telihat perbedaan yang nyata hal ini pada umur 40 hari fusarium masih membentuk koloni diluar tanaman nyakni dalam tanam belum masuk

Dalam hal efisiensi dapaat dikatakan bahwa pada saat dosis pemberian 30 gr/bibit secara statistika sudah menunjukkan efisiensi jika dikaitkan kedalam tanaman, sehingga belum tampak serangan, sedangakan pada umur 60 hari telah mulai masuk kedalam tanaman tanaman dan mulai menyerang dan pada umur 120 hari telah nyata menyerang sehingga terlihat perbedaan intensitas serangan yang nyata pada perlakuan yang tidak diberikan trichoderma.

dengan infestasi dan pada dosis $45 \mathrm{gr} /$ bibit sudah menjadi tidak efisien lagi karena membutuhkan investasi yang 
besar dalam hal pengadaan trichoderma sp.

\section{Pengaruh Interaksi}

Hasil uji $\mathrm{F}$ memperlihatkan bahwa bahwa pemberian trichoderma sp tidak interaksi tidak berpengaruh nyata terhadap semua para meter yang diamati, hal ini mengindikasikan tergantung poada jenis tanaman pisang.

\section{KESIMPULAN}

\section{Kesimpulan}

1. Efisiensi penggunaan trichoderma sp terjadai pada dosis $30 \mathrm{gr} /$ bibit pisang.

2. Jenis pisang pada awal pertumbuhan sangat berpengaruh terhadap perkembangan nbibit btanaman pisang

3. Dosis trichopderma sp berpengaruh sangat nyata

\section{Saran}

Perlu dilakukan penelitian lebih lanjutan di laahan yang terkontamina langsung sehinbgga

hasilnya lebih dapat diterapkansung pada lahan kebun petani.

\section{DAFTAR PUSTAKA}

Azwar, 2008. Bercocok Tanam Perkebunan Tahunan. Gajah Mada University Press, Yokyakarta.

Dwiastuti, ME., M.N. Fajri, dan Yunimar, 2015. Potensi Trichoderma spp sebagai Agens Pengendali Fusarium spp penyebab penyaakit layu pada Tanaaman Stroberi (Flagaria $x$ ananessa Dutch.). Balai Penelitian Janaman jeruk

dan Buah Subtropika, Malang, J. Hort : 25 (4) . 331-339.

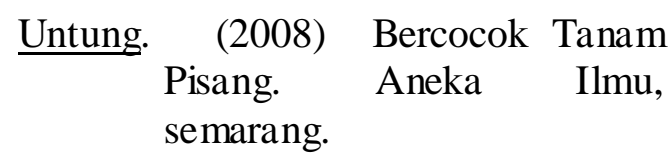

Rismunandar, dan Sunaryono H. 1999. Pengantar Pengaetahuan Dasar Holtikultura, Sinar Baru. Bandung.

Siregar. T. H., S. Riyadi, L. Nuraeni. 
2000. Budidaya Pengolahan dan Pemasaran Coklat. Penebar Swadaya, Jakarta.

Sitepu, F. E., Lisnawita dan M. I. Pinem. 2014. Penyakit Layu Fusarium (Fusarium oxysporium f.sp. cubense F.F. Smith) Synd \& Hans) pada Tanaman Pisang (Musa spp) dan Hubungannya dengan Keberadaan Nematoda (Rdopholus similis) di Lapangan. Jurnal Online Agroekoteknologi, Medan. 2 (3) : 1204-1211.

Sudirman, A., Sumardiyono, C dan S. M. Widyastuti, 2011. Pengendalian Hayati Penyakit Layu Fusarium Pisang (Fusarium oxysporium f.sp. cubense) dengan Trichoderma, sp. Jurnal Perlindungan Tanaman Indonesia, Yogyakarta . 17 (1) : 31 35.

Susanto, H. 1994, Budidaya, F. X. 1994, Tanaman Pis,ang Budidaya dan Pengolahan Hasil. Kanisius, Yokyakarta,

Wididana, G.N. 1993. Peranan Effective Microorganisme dalam Meningkatkan Kesuburan dan Produktivitas Tanah. Indonesian Kyusei Nature Farming. Diakses 02 April 2013)

Zulkarnain, 2009. Zat Pengatur Tumbuh Pengenalan dan petunjuk penggunaan pada Tanaman. Jakarta 